\title{
An Ecocritical Approach to Chinua Achebe's Things Fall Apart and Arrow of God.
}

\author{
Gitanjali Gogoi \\ Asst. Professor (English) N.N. Saikia College, Titabar. Jorhat. Assam.
}

\begin{abstract}
Ecocriticism is the study of literature in relation with environment and nature. The urgency of examining literature from an ecological point of view is occasioned by the present environmental crisis swept the globe. Ecocriticism tries to find possible solution to correct contemporary ecological situation by analyzing the ways nature and environment are represented in literature. The bringing together of ecocriticism and postcolonialism has given a new impetus to the whole critical thought where the ideas of race, land, environment, wilderness etc. are given new insight. Though the two African novels undertaken for analysis have rarely been viewed from an ecocritical perspective, the present paper would make an attempt to examine how nature and environment are being treated in them. Such an examination is intended to establish that, while the pre colonial African society lived in an inviolate state of nature, it was colonialism that opened the door for exploitation of nature, ignoring or denigrating the deep meanings that nature and environment held for the African people in the pre colonial period.
\end{abstract}

Key words: Africa; agriculture; earth; ecology; Postcolonialism; religion.

\section{Introduction}

Ecocriticism is a recent evolution in the area of literary appreciation. Evolved first in the US and then in UK, it gained a momentum only during the 1990s. From the very inception, ecocriticism has been based on the assumption that human world and the physical environment are closely interlinked and that one is shaped by the other and therefore the study of the representation of human-nature relationship in literature is of utmost important to understand the environmental predicament of today's world. William Rueckert was the first person to have used the term 'ecocriticism' in his essay "Literature and Ecology: An Experiment in Ecocriticism" published in 1978. He defined the term as the application of ecology and ecological concepts to the study of literature. However a remarkable book came out in the year 1996 which gave a new turn to the whole movement of ecocriticism. It was The Ecocriticism Reader: Landmarks in Literary Ecology edited by Cheryll Glotfelty and Harold Fromm. Published with a number of articles with themes of nature and environment, this book established itself as a milestone in ecocriticism. Here Glotfelty gives the oft quoted definition of ecocriticism:

What then is ecocriticism? Simply put, ecocriticism is the study of the relationship between literature and physical environment. Just as feminist criticism examines language and literature from a gender conscious perspective, and Marxist criticism brings an awareness of modes of production and economic class to its reading of text, ecocriricism takes an earth centered approach to literary studies. (xviii)

Thus ecocriticism is based on the idea that the physical world and the human culture are connected and are affected by each other. It examines the relationship between the human and the non-human represented in literary texts. Ecocritics study the ways nature is portrayed in the body of the text and attempt to analyze their relevance with environmental crises. Hence the study of nature is directed towards an understanding of the imbalance of the eco system in the contemporary world.

The present day environmental predicament is a sure result of the age old practice of exploitation of nature and abuse of the environment for the benefit of human civilization. While the reshaping of nature has been executed throughout human history, the episode of European colonialism is the most outstanding example of human interference with nature as the whole enterprise of colonization was based on the idea of exploiting nature and its resources. The Western cultural tradition of using nature for human benefits was most strongly propounded through colonialism. In fact, it is not only during the era of colonization, but the practice against nature is being carried out in the neocolonial period in the present day circumstances. Therefore the blame for environmental crisis falls primarily on the West as it is inspired by the Western principle of separation of the human from the non-human. This very point calls for analysis of ecological concepts in literature from a postcolonial perspective. The ever broadening horizon of ecocriticism has broadened its potentiality by its "cross-pollination with postcolonial studies" (Buell. 93) and this merger has provided a deeper understanding of the issue of environmental degradation in present age.

The convergence of postcolonialism with ecocriticism is justified from the point that colonial exploitation of nature was inspired by European Enlightenment philosophy, knowledge of nature, conservation 
policy etc. and therefore "to deny colonial and environmental histories as mutually constitutive misses the central role the exploitation of natural resources plays in any imperial project." (DeLoughrey. 10) Though postcolonial criticism has been anthropocentric from the beginning, the devastating impact of neocolonialism over the ecosystem of non-European nations has made postcolonial studies discover "its commitment to the environment, reiterating its insistence on the inseparability of current crises of ecological mismanagement from historical legacies of imperialistic exploitation and authoritarian abuse." (Huggan. "'Greening' Postcolonialism". 702) So ecocriticism without postcolonial perspective would mean to study only the tip of the iceberg while the history of colonialism has hidden inside it the genesis of the problem.

In the present scenario of environmental degradation, postcolonial writers from non-European nations have come forward to finger out the ills of neocolonialism and globalization. In Africa, a number of writers and critics, without the stamp of ecocritics, have traditionally been engaged in nature writing highlighting land issues, environmental evils studying them as the result of the long history of colonialism. William Slaymaker in his essay "Ecoing the Other(s): The Call of Global Green and Black African Responses" perceives that many African writers' resistance or avoidance of ecocritical paradigms is caused by their suspicion about a Western theory which "appears as one more hegemonic discourse from the metropolitan West" (Slaymaker. 132) and because African writers do not expect any Western theory to solve their environmental problems. However, without being called ecocritics, African writers are extremely serious about nature and environment. Niyi Osundare and Ken Saro Wiwa, both belonging to Nigeria, were famous writers along with being committed eco activists. From such perspectives, the position of Chinua Achebe is not easy to define. Though Achebe has not shown any apparent awareness towards ecological crisis in his writings, his novels, mainly Things Fall Apart (1958) and Arrow of God (1965) bear sufficient proof of the writer's addressing the theme of nature and environment. While the first novel is set in the pre colonial Igbo land of southeastern Nigeria, the second novel has the early colonial period as its backdrop. Accordingly, the first novel gives a picture of nature and environment in their inviolate state, and the second novel shows the violation of the same due to colonial invasion.

\section{Ecocriticism and Chinua Achebe's Novels}

Franz Fanon, in The Wretched of the Earth, had commented: "For a colonized people the most essential value, because the most concrete, is first and foremost the land: the land which will bring them bread and, above all, dignity." (34) Chinua Achebe, in Things Fall Apart, portrays this spiritual relation between the Igbos and their natural world, a relation that went beyond the visible physical correspondence. Set in a village called Umofia, Achebe portrays nature as another character in the novel, not just keeping it in the background. He presents nature as a living entity which acts along with the human characters. That the idea of exploiting nature for their own benefit is unimaginable for the Igbos is apparent in their physical activities and mental thinking which are shaped by the surrounding environment. Achebe shows how the Igbos' agricultural life, religious beliefs, festivals, their ideas about the world and human life are all intertwined with nature.

In the first place, mention must be made of the different individual and community activities observed in different seasons. Igbos maintained strict rules during the planting and harvest seasons. They believed that any violation of the nature's course would dissatisfy the earth. For example, maintaining the 'week of peace' was compulsory before the first plantation of yams. As yam was a sacred food for the Igbos, they maintained equal sanctity before its plantation. They believed that maintenance of peace in domestic and societal level kept the earth satisfied which would ensure good harvest. Therefore, when Okonkwo, the protagonist, broke the sanctity of the week being violent to his wife, he had to face heavy penalty to compensate the harm he had committed against nature. One of Okonkwo's neighbors reprimanded him this way: "You know as well as I do that our forefathers ordained that before we plant any crops in the earth we should observe a week in which a man does not say a harsh word to his neighbor. We live in peace with our fellows to honor our great goddess of the earth without whose blessing our crops will not grow. You have committed a great evil." (Things Fall Apart. 30) During the 'week of peace', Igbos did not do any work on the land. This practice of keeping the earth away from any work showed Igbos' great concern for nature which they considered as a living being that needed rest prior to yearlong labor. After the 'week of peace' both men and women became extremely busy along with the earth to plant and grow new yams. Again the New Yam Festival was observed with all sincerity as "It was an occasion for giving thanks to Ani, the earth goddess and the source of all fertility. Ani played a greater part in the life of the people than any other deity. She was the ultimate judge of morality and conduct." (36)

The respect that the Igbos held for their ancestors was another evidence of their great love for the land. Their ancestors were the very part of the land. In describing the burial ground of the community, Achebe narrates: "The land of the living was not far removed from the domain of the ancestors. There was coming and going between them ..." (122) Thus the dead members of the community became a part of the land. "This dynamic model of land extends genealogically from the past to the future." (DeLughrey. 6) Nature was thus 
appropriated by the Igbos to include both the living and the non-living members of the community. The land did not belong to the present generation only, the ancestors and the future generations too shared the land.

For the Igbos, nature was divine. Trees, rivers, hills, cave, and different other components of the environment held divine powers. Ani was the goddess of earth and fertility, Amadiora, the god of thunder, Ufiojioku, the god of harvest and Anyanwu was the sun god. Igbo believed in the Oracle of Hills and Caves and obeyed its command with utmost sincerity. There was a mention of a "big ancient silk-cotton tree which was sacred. Spirits of good children lived in that tree waiting to be born. On ordinary days, young women who desired children came to sit under its shade." (46) Igbos believed that the divine nature influenced human life from birth till death and even after that; any violation of the natural setting meant to disrupt the flow of life. Any occurrence that appeared unnatural such as twin babies, diseases like small pox and leprosy, death by suicide etc. were handled in different ways. For such cases Igbos had a reserved area called the Evil Forest where they deposited such persons. Things which were incomprehensible or beyond control were submitted to nature.

Again, Achebe shows how the language of the Igbos was shaped by the landscape. Being an oral society, Igbos used numerous oral devices for effective communication, such as proverbs, sayings, riddles, myths etc. in their conversation. Frequent references to flora and fauna implied the Igbos' closeness to nature. Proverbs like 'Okonkwo's fame had grown like a bush-fire in the harmattan' (2), 'A toad does not run in the day time for nothing' (20), 'Obierika's house is as busy as an ant hill' (79) etc. and numerous other were influenced by their environment. Achebe incorporates a number of myths and folk tales to establish the same point. The myth of the Cosmic Quarrel between Earth and Sky, the Locust myth, the Mosquito myth, the folk tale of the Tortoise and Birds etc. were evidences of how their folktales were products of the land and the landscape. Regarding this aspect, DeLoughrey observes "The post colonial ecology of Things Fall Apart is evident in the way that language develops in a long historical relationship to a particular environment and culture."(7) Thus, nature shaped the mental make-up of the Igbos which was reflected in the language.

After giving a complete picture of the pre colonial Igbo life, Achebe moves to show how the Christian missionaries and colonial rulers denigrated the philosophy of the native peoples. In their attempt to spread Christianity, the missionaries, the harbingers of colonial rule, stripped from nature and environment all the spiritual meanings held deeply by the Igbos. They tried to persuade the local people to embrace Christianity by establishing that the Igbo religion was pagan and all their religious beliefs were baseless. The missionary Mr. Brown tried to convince that nature did not hold any divine power and there was only one god i.e. Christ. $\mathrm{He}$ said: "You carve a piece of wood and you call it god. But it is still a piece of wood." (179) Thus all other deities of nature were dismissed and made fun of by the missionaries. It can be said that construction of church building by cutting down the trees of the Evil Forest not only wounded Igbos' religious beliefs, but it also marked the destruction of nature for the advancement of colonial enterprise.

In the final scene, when Okonkwo hanged himself, it was an "offense against the earth. His body is evil, only strangers may touch it." (207) As the Igbos believed that man must be a part of the surrounding nature after his death, Okonkwo, who went against nature by killing himself, did not deserve a burial and so must not be allowed to be a part of nature. But all the meanings attached to such a death was immediately denied by the colonial official who only found the incident 'interesting' enough to be included in the book he was writing.

By giving a heart-rending portrayal of how the Igbos' deeply reverenced values were negated by the colonial rulers, Achebe's novel thus indicates the initial stage of what was going to take a devastating turn in the history of colonial exploitation. Things Fall Apart is the evidence that the act of violating nature and destructing the environment was inspired by very principles of the colonial rule which did not believe in the spiritual bond between nature and human beings. While colonial exploitation was in its initial stage in Things Fall Apart, it appeared in full aggression in Arrow of God. Again, the background of this novel is an Igbo village called Umuaro now under colonial rule which was slowly but surely making its way inside the traditional life of the Igbos disrupting their age old belief system.

Here again we get a picture of a rural Igbo community living with nature. The life and living of these Igbos revolved around the occurrences of nature. The harvest and planting of Igbo chief food yam depended on the appearance of the moon in the night sky. The task of tracking the lunar movement to mark the passage of time and declare the harvest and planting season was carried on by Ezeulu, the protagonist of the novel, who was the chief priest of the village. The dependence on nature was such that if Ezeulu failed to declare the sight of the new moon, no harvest or plantation would be done. As the colonial rulers could hardly understand the gravity of Ezeulu's role in the community, they imprisoned him for two months because he refused to be appointed as the warrant chief. This resulted in his failure to keep track of time and declare the harvest season. Consequently, when the whole village fell into famine because of Ezeulu's delay of declaring the harvest, Christian missionaries offered to save them through conversion. Though the villagers were restored to life, the harvest and planting of yam had to lose their spiritual significance under the impact of Christianity.

The disruption of the Igbos' strong bond with the environment was symbolized by another incident related to the python. For the Igbos, the royal python was extremely sacred and was a sign of divinity. But the 
Christian missionaries encouraged the people kill the python by calling it a mere snake "the snake that deceived our first mother, Eve." (Arrow of God, 48) Such words provoked Oduche, Ezeulu's son, to kill the python by imprisoning it inside a box.

Achebe shows how the different objects of the environment such as rivers, hills, trees, stones were the store houses of stories and legends. For example, the story associated with the stream Ota was a case in point. As the story goes, Ota had been temporarily abandoned as "the enormous boulder resting on two other rocks at its source was about to fall and would take a softer pillow for its head ..." (7) While Achebe incorporates numerous other stories to prove nature as a living entity for the Igbos, he also indicates that the colonial rulers did not find it beautiful and welcoming, let alone its spiritual value. He points out how George Allen (the colonial official from Things Fall Apart), now the writer of the book The Pacification of the Primitive Tribes of the Lower Niger, reflected his uneasiness towards the abundance of Africa's nature calling it the "deadly fertility" (34) of the land.

Construction of a road between Umuaro and Okperi was a significant example of future colonial projects to connect different parts of the region solely for the benefit of the colonizers. Moreover, the road marked the cutting down of dense forests of the land leaving a physical scar on its body. Though the road enforced the colonizers' mental map of Africa eliminating the 'deadly fertility' of the land, the open area created discomfiture in the minds of the natives as "the feeling of openness and exposure made him [Obika] alert" (82). Destroying the forest also meant interrupting nature's course by depriving the deities of their homes.

The ending of the novel marked the triumph of colonial power as the famine left the villagers with no alternative but to embrace Christianity and come completely under colonial rule. Harvesting yam in the name of the Christian god marked the replacement of Igbo spirituality with a western material culture where the bond between nature and culture did not exist. This end marked the beginning of a new era in which the Igbos' holistic philosophy would be displaced and the western ideas of development and progress (at the cost of nature and environment) would be established. So what was anticipated in Things Fall Apart became a reality in Arrow of God.

\section{Conclusion}

Thus the importance of Postcolonial Ecocriticism is felt necessary to apply to these two African novels as "Postcolonial studies have come to understand environmental issues not only as central to the projects of European conquest and global domination, but also as inherent in the ideologies of imperialism and racism on which those projects historically - and persistently - depend." (Huggan et al. Postcolonial Ecocriticism. 6) It was not only during the colonial period, but even after the end of colonial rule, developmental projects master planned in Western countries have been continuously robbing nature of its riches and degrading the environment.

This paper is concluded with the note that Postcolonial Ecocriticism can play a crucial part in the study of present environmental degradation. This critical school can throw new insight into the western ideas of development which, under the disguise of neocolonialism, has been a cause of global environmental crises. A balanced view of development is the need of the hour and postcolonial ecocriticism can contribute to global justice and sustainability by exploring themes centered on nature and environment across different literary works.

\section{References:}

[1]. Glotfelty, Cheryll. Introduction. The Ecocriticism Reader: Landmarks in Literary Ecology. Ed. Cheryll Glotfelty and Harold Fromm. USA: University of Georgia Press, 1996. pp. xv - xxxvii.

[2]. Buell, Lawrence. "Ecocriticism: Some Emerging Trends.” Qui Parle: Critical Humanities and Social Sciences. Vol. 19. No. 2 ( 2011): pp. 87-115

[3]. DeLoughrey, Elizabeth M. and George B. Handley. Ed. Introduction. Postcolonial Ecologies: Literature of the Environment. New York: Oxford UP, 2011.3 - 42

[4]. Huggan, Graham. "Greening Postcolonialism: Ecocritical Perspectives." Modern Fiction Studies. Vol. 5o. No. 3 (2004): pp. 701 733.

[5]. Slaymaker, William. "Ecoing the Other(s): The Call of Global Green and Black African Responses." PMLA. Vol. 116. No. 1(2001): pp. 129-144.

[6]. Fanon, Franz. The Wretched of the Earth. Trans. Constance Farrington. London: Penguin,1963.

[7]. Achebe, Chinua. Things Fall Apart. New York: Anchor Books, 1994.

[8]. _ - _ Arrow of God. London: Penguin Books, 2010

[9]. Huggan, Graham and Helen Tiffin. Postcolonial Ecocriticism: Literature, Animals, Environment. USA: Routledge, 2010. 